\title{
Upaya Peningkatkan Brand Awareness PT. Go-Jek Indonesia Melalui Aktivitas Marketing Public Relations
}

\author{
Umaimah Wahid dan Anggun Eka Puspita \\ Universitas Budi Luhur \\ umaimah.wahid@budiluhur.ac.id, angguneka06@gmail.com
}

\begin{abstract}
Online transportation is nowadays popular in Indonesia and becomes a new alternative for people due to its efficiency and effectivity. One of the most famous online transportations is PT.Go-Jek Indonesia. People prefer to choose it to anticipate traffic jam in Jakarta and the surroundings. Besides PT. Go-Jek, there are some similar transportations such as PT.GRAB, UBER, and so on. This condition caused the competition among the online transportations resulting in the necessity to create a strong brand around the people. In accordance to that matter, the role of public relation is quite significant to increase Brand awareness in society. This research focus on the role of public relations to increase the brand awareness of PT Go-Jek using the theory of mixed public relation strategy by Thomas L. Harris that is famous of his concept, 'P.E.N.C.I.L.S'. The method of this research is case study by interview completed by data as data collection technique. The activity of public relations involves the 7 strategies of public relation to increase brand awareness. The activities were for example publication, holding interesting events, establishing good relationship with society, cooperating with other companies, creating a positive image, providing services and new features for the society. Those are meant to show that PT. GO-JEK gives the best service for customers and society to strengthen the brand awareness of PT. Go-Jek. Those efforts of PT Go-Jek resulted in increasing the brand awareness so that society chooses that online transportation as an alternative of nowadays internet-based transformation.
\end{abstract}

Keywords: brand awareness, image, marketing public relations,

\begin{abstract}
Abstrak
Transportasi online saat ini marak di Indonesia dan menjadi alternatif baru bagi masyarakat karena efisien dan efektif. Salah satu transportasi online yang fenomena adalah PT. Go-Jek Indonesia yang menjadi pilihan masyarakat dalam mengantisipasi kemacetan Jakarta dan sekitarnya. Selain PT. Go-Jek, terdapat beberapa transportasi sejenis lannya yang beroperasi seperti PT.GRAB, UBER dan lainnya. Kondisi tersebut memunculkan persaingan di antara perusahan-perusahaan transportasi online yang harus menciptakan brand yang kuat di tengah masyarakat. Dalam Upaya tersebut peran public relations sangat penting untuk meningkatkan Brand Awareness di masyarakat. Fokus penelitan ini adalah peran public relations dalam mingkatkan kesadaran mereka PT. GoJek. Menggunakan teori strategi bauran pemasaran Humas Thomas L. Harris yang terkenal dengan konsep 'P.E.N.C.I.L.S'. Metode penelitian adalah studi kasus dengan teknik pengumpulan data wawancara dan dilengkapi data. Kegiatan marketing public relations berlaku dalam meningkatkan brand awareness ke 7 strategi marketing public relations. Kegiatan seperti publikasi, melaksanakan kegiatan-kegiatan menarik, establishgood hubungan dengan masyarakat, menjalin kerjasama dengan perusahaan lain,
\end{abstract}


meningkatkan citra positif, menyediakan layanan, dan menambahkan fitur baru dalam jaringan yang disediakan kepada masyarakat. Semua hal itu sebagai upaya yang serius dan sungguh-sungguh PT. Go-Jek memberikan pelayanan terbaik kepadakonsumen khususnya dan masyarakat umum agar kesadaran merek PT. Go-Jek semakin kuat.

Kata Kunci: brand awareness, citra, marketing public relations,

\section{Pendahuluan}

PT. Go-Jek adalah salah atau transportasi berbasis internet di Indonesia. Kehadiran Go-Jek sebagai bentuk implikasi dari perkembangan teknologi dan meluasnya penggunaan internet dan smartphone di tengah masyarakat. Adanya aplikasi dan roda bisnis dalam bidang transportasi nampaknya sudah mengubah cara masyarakat menggunakan transportasi dari cara konvensional ke arah tranportasi berbasis internet. Peningkatan jumlah pengguna internet berdampak pada jumlah pengguna jaringan sosial media melalui smart phone sehingga masyarakat cenderung beralih menggunakan transportasi berbasis internet. Kemunculan aplikasi ojek online, misalnya, telah mengubah perilaku sebagian orang dalam mendapatkan layanan ojek. Riset MarkPlus terbaru menyebutkan bahwa sekitar 98\% anak muda di Indonesia memiliki handphone. Sedangkan sebanyak $71 \%$ dari mereka mengakses internet setiap hari. Durasinya sangat variatif, mulai dari tiga jam sekali hingga empat jam sekali. Namun, rupanya tren online ini juga memberi dampak kepada sebagian tukang ojek yang tidak go online. Kemunculan aplikasi ojek online, misalnya, telah mengubah perilaku sebagian orang dalam mendapatkan layanan ojek. Selain itu, layanan ojek online ini juga makin berkembang dengan layanan antar makanan atau paket barang. (Devi, 2015)

Jumlah pengguna internet pada Indonesia telah mencapai angkat 88,1 Juta. Bila dibandingkan menggunakan jumlah penduduk Indonesia yg terdapat 252,4 Juta, maka dapat dikatakan bahwa penetrasi pengguna internet pada negara ini mencapai $34,9 \%$. Nomor tersebut meningkat relatif banyak bila dibandingkan dengan data pengguna tahun 2013 dimana penetrasi internet baru mencapai 28,6\%. (Internet, 2015). Kenaikan jumlah pengguna internet sangat signifikan. Berdasarkan data yang dihimpun We Are Social, terjadi kenaikan pengguna internet di Indonesia selama setahun, mulai Januari 2015 sampai Januari 2016, yakni sekitar 15 persen. Kenaikan jumlah pengguna internet tersebut juga berimbas pada pengguna media sosial yang kian banyak. Meskipun tak sebanyak kenaikan pengguna internet, pengguna media sosial yang aktif bertambah sekitar 10 persen dari Januari tahun lalu.

Transportasi ojek yang berbasis online sebenarnya membantu dalam mengefektifkan dan jauh lebih efesien. Fenomena tersebut Go-Jek masuk dengan terobosan yang berbasis online. Didirikan pada tahun 2011. Go-Jek bermitra dengan para pengendara ojek berpengalaman dan menjadi solusi utama dalam pengiriman barang (Go-Send), pesan antar makanan (Go-Food), berbelanja (GoMart) dan berpergian (Go-Ride) ditengah kemacetan (www.Go-Jek.com). Go-Jek menjadi transportasi alternatif pilihan masyarakat kota besar yang macet. Kepopuleran Go-Jek menarik banyak pihak, beberapa enterpreuner mengikuti 
jejak Go-Jek dengan mendirikan perusahaan ojek berbasis online juga. Sampai saat ini terdapat 6 ojek online yaitu GrabBike, Smartjek, BangJek, Taksi Jeger, Ojesy, dan Bluejek. (Winarta, 2015)

Munculnya beberapa perusahaan yang menjalankan bisnis sejenis dengan PT. GO-JEK telah memunculkan persiangan bisnis diantara perusahan-perusahaan tersebut. Dalam upaya memenangkan persaingan bisnis dan upaya merebut pelanggan, PT. GO-JEK melakukan berbagai aktivitas untuk menghasilkan peningkatan keasadaran merek di tengah masyarakat. PT. GO-JEK harus berusaha memenangkan persepsi positif dari masyarakat sehingga menumbuhkan image positif yang akan memperkuat kesadaran merek perusahaan.

PT. Go-Jek didirikan oleh Nadin Makariem yang bersifat bisnis startup, terdapat misi sosial yang diemban ketika mendirikan Go-Jek, yakni meningkatkan penghasilan para supir ojek. Nadiem mendirikan Go-Jek bermula dari obrolannya dengan supir ojek di pangkalan dan menyimak dan menyimpulkan bahwa waktu kerja supir ojek pangkalan tidak reproduktif, sebab lebih dari sebagian waktu kerja supir ojek habis hanya untuk menunggu pelanggan. Kemacetan semakin padat, sehingga ojek online harusnya bisa menjadi solusi alternatif untuk masyarakat ibu kota. Alasan tersebut yang melahirkan gagasan untuk menciptakan layanan transportasi antar yang praktis \& cepat untuk membantu masyarakat pengguna ojek, sekaligus membantu para supir ojek agar bisa bekerja lebih produktif. Hingga pada tahun 2010, akhirnya Go-Jek diluncurkan dan mulai beroperasi (Go-Jek, 2015)

PT. Go-Jek sebagai perusahaan transportasi online memerlukan upaya marketing public relations untuk memperkenalkan perusahaan kepada masyarakat, terlebih adanya persaingan diantara perusahaan jenis yang sama. Berbagai kegiatan dalam upaya PT. Go-Jek membangun dan mempromosikan perusahaannya dengan kreatifitas dan strategi yang berbeda-beda yang dapat menarik perhatian masyarakat dengan sebaik mungkin.PT. Go-Jek melakukan kegiatan-kegiatan yang mendukung pembentukan bahkan penguatan image perusahan secara terencana dan terus-menerus sehingga diharapkan dapat memenangkan hati masyarakat.Kegiatan tersebut merupakan bagian dari kegiatan marketing public relations untuk menciptakan presepsi masyarakat untuk membangun brand awareness. PT.Go-Jek harus mampu meningkatkan kegiatan marketing-nya agar dapat terus memenangkan pasar dibanding dengan ojek online lainnya.

PT. Go-Jek sebagai perusahaan transportasi online yang merupakan jenis transportasi baru berbasis internet, memerlukan sebuah upaya yang serius untuk membangun merek (brand) di kalangan masyarakat pengguna smartphone. Upaya pembangun merek terkait langkah-langkah pemasaran yang diterapkan oleh PT. Go-Jek ditengah persaingan denganh merek dagang lainnya yang mau-tidak mau memunculkan persaingan yang ketat untuk memenangkan hati masyarakat sebagai konsumen. Menurut Thomas L. Harris (2006) muncul dan berkembangnya Marketing Public Relations (MPR) saat ini dapat dilihat dari fenomena yang ada yaitu:

1. Public Relations has become a big and profitable business. (Public Relations sudah menjadi suatu yang besar dan bisnis yang menguntungkan). 
2. MPR is the largest and fastest growing segment of a fast growing industry. (MPR adalah bagian pertumbuhan yang paling besar dan paling cepat dalam suatu pertumbuhan industri yang paling cepat pula).

3. Companies have recognize the growing importance of marketing public relations with bigger budget and fatter paychecks. (Perusahaan telah mengakui semakin meningkatnya arti penting MPR, maka besarnya anggaran dan cek gaji yang lebih besar pula).

4. Public Relations is getting increasing interest in the marketing and business media. (Public Relations mulai menambah minat di media pemasaran dan perusahaan).

5. The academic community is showing greater interest in public relations. (Himpunan akademis menaruh perhatian yang lebih baik terhadap Public Relations).

Marketing public relations (MPR) melakukan berbagai upaya untuk membangun atau meningkatkan kesadaran merek perusahan agar menjadi pilihan khalayak. Diperlukan sebuah usaha yang terus menerus untuk membangun kesadaran merek sehingga mencapai level tertinggi yaitu top of mind. Tentu saja upaya yang dilakukan PT.Go-Jek dengan memperkenalkan produk kepada masyarakat, membangun image yang kuat dan dipercaya mempunyai nilai yang menguntungkan dan memberikan solusi akan kebutuhan masyarakat terhadap transportasi yang mudah, murah dan aman. Kesadaran yang tumbuh pada konsumen berimplikasi signifikan pada keberhasilan sebuah perusahaan dalam memenangkan pikiran masyarakat dan sekaligus mampu memengkan persiangan bisnis.

Kekuatan nilai merek (brand values) sebuah produk adalah 'sesuatu yang ditawarkan atau dijanjikan kepada masyarakat' dalam proses pemasaran yang dilakukan. Pengertian brand menurut David A. Aaker (Ruslan 2010) adalah nama dan simbol yang bersifat membedakan (seperti sebuah logo, cap, atau kemasan) dengan maksud, mengidentifikasikan barang dan jasa dari seorang penjual. Kesadaran merek (brand awareness) adalah kemampuan sebuah merek untuk muncul dalam benak konsumen ketika mereka sedang memikirkan kategori produk tertentu dan seberapa mudahnya nama tersebut muncul. (Shimp, 2003) Definisi lainnya menyatakan bahwa brand awareness sebagai kesanggupan seorang calon pembeli untuk mengenali, mengingat kembali suatu merek sebagai bagian dari suatu kategori produk tertentu (Durianto dkk, 2004).

Terdapat beberapa tingkatan brand awareness dalam proses pembentukan dalam kegiatan perusahaan, yaitu: 1) Unaware of brand, pada tahapan ini, pelanggan merasa ragu atau tidak yakin apakah sudah mengenal merek yang disebutkan atau belum. Tingkatan ini yang harus dihindari oleh perusahaan; 2) Brand recognition, pada tahapan ini, pelanggan mampu mengidentifikasi merek yang disebutkan; 3) Brand recall, pada tahapan ini, pelanggan mampu mengingat merek tanpa diberikan stimulus; dan 4) Top of mind, pada tahapan ini pelanggan mengingat merek sebagai yang pertama kali muncul di pikiran saat berbicara mengenai kategori produk tertentu. (MarkPlus, 2010; lihat juga Durianto, Sugiarto dan Lie Joko Budiman, 2004) 


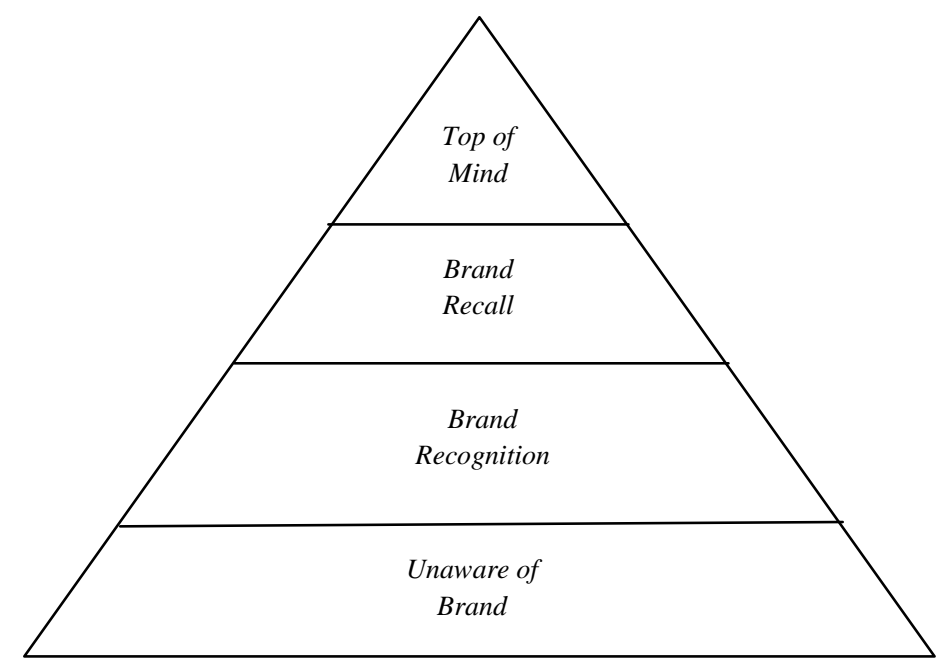

Gambar 1: Tingkatan Kesadaran Merek (Sumber: Durianto, Sugiarto dan Lie Joko Budiman, 2004)

Bauran P.E.N.C.I.L.S yang dikembangkan oleh Thomas L. Harris jika dijabarkan secara rinci dalam korelasi komponen utama peranan public relations adalah:

a. Publications (Publikasi dan publisitas) adalah menyelenggarakan publikasi atau menyebarluaskan informasi melalui berbagai media tentang aktivitas atau kegiatan perusahaan atau organisasi yang pantas untuk diketahui oleh publik. Setelah itu, menghasilkan publisitas untuk memperoleh tanggapan positif secara lebih luas dari masyarakat.

b. Event (Penyusunan program acara), merancang acara tertentu atau lebih dikenal dengan peristiwa khusus (special event) yang dipilih dalam jangka waktu, tempat, dan objek tertentu yang khusus sifatnya untuk mempengaruhi opini public.

c. News (Menciptakan berita), Berupaya menciptakan berita melalui pers realease, news letter dan bulletin, dan lain-lain. Public Relations Officer (PRO), mau tidak mau harus mempunyai kemampuan untuk menulis, karena sebagian besar tugasnya untuk tulis-menulis (PR writing), khususnya dalam menciptakan publisitas.

d. Community involvement adalah mengadakan kontak sosial dengan kelompok masyarakat tertentu untuk menjaga hubungan baik (community relations and humanity relations) dengan pihak organisasi atau lembaga yang diwakilinya.

e. Inform or image yaitu memberitahukan sesuatu kepada publik atau menarik perhatian, sehingga diharapkan akan memperoleh tanggapan berupa citra positif dari suatu proses "nothing" diupayakan menjadi "something". Dari yang tidak tahu menjadi tahu, setelah tahu menjadi suka, dan kemudian diharapkan timbul sesuatu (something) yaitu berupa citra.

f. Lobbying and negotiation, yaitu kemmapuan melobi dan negosiasi yang sangat diperlukan bagi seorang Public Relations Officer (PRO) agar semua terencana, ide atau gagasan kegiatan suatu lembaga atau organisasi 
sebelum dimasyarakat perlu diadakan pendekatan untuk mencapai kesepakatan (deal) atau memperoleh dukungan dari individu dan lembaga yang berpengaruh sehingga timbul saling menguntungkan (win-win solution).

g. Social Responsibility yaitu aspek tanggung jawab sosial sebuah perusahaan dan tidak hanya memikirkan keuntungan materi bagi lembaga atau organisasi serta tokoh yang diwakilinya, tetapi juga kepedulian kepada masyarakat untuk mencapai sukses dalam memperoleh simpati atau empati dari khalayak-khalayaknya. (Ruslan, 2013)

\section{Metode Penelitian}

Penelitian ini menggunakan pendekatan kualitatif, yaitu pendekatan yang tidak mengandalkan bukti berdasarkan logika matematis, prinsip angka atau metode statistik. Pembicaraan yang sebenarnya, isyarat dan tindakan sosial lainnya adalah bahan mental untuk penelitian kualitatif.“ (Mulyana, 2003). Metode penelitian yang digunakan adalah studi kasus, yaitu metode studi kasus, yaitu sebuah metode penelitian yang kekuatannya terletak pada kemampuan untuk menggunakan berbagai sumber dan atau evidences yang tersedia sehingga dapat memperoleh jawaban dari permasalahan yang diteliti. Berbagai bentuk sumber data yang dimaksud adalah dokumen, artifact, interview dan juga observasi (Yin, 1989). Studi kasus berlaku apabila suatu pernyataan 'bagaimana' (how) dan mengapa (why) diajukan terhadap seperangkat peristiwa aktual yang mustahil atau setidaknya sukar dikontrol oleh periset (Yin, 1981 dalam Salim, 2006).

Metode studi kasus yang digunakan dalam penelitian ini adalah studi kasus yang bersifat kolektif (collective case study). Collective case studi dilakukan untuk menarik kesimpulan atau generalisasi atas fenomena atau populasi dari kasus-kasus tersebut (Salim, 2006). Bila dilihat dari tujuannya, studi kasus merupakan salah satu metode penelitian kualitatif yang berbasis pada pemahaman dan perilaku manusia berdasarkan perbedaan nilai, kepercayaan dan scientific theory (Polit \& Beck, 2004). Pendekatan penelitian yang digunakan pada penelitian ini adalah pendekatan kualitatif. "Pendekatan kualitatif tidak mengandalkan bukti berdasarkan logika matematis, prinsip angka atau metode statistik. Pembicaraan yang sebenarnya, isyarat dan tindakan sosial lainnya adalah bahan mental untuk penelitian kualitatif.“ (Mulyana, 2003).

Berdasarkan tataran atau cara menganalisis data, menurut Kriyantono (2010) dikenal beberapa jenis atau tipe riset, yaitu:

1) Jenis Eksploratif. Riset ini untuk menggali data, tanpa mengoperasikan konsep atau menguji konsep pada realitas yang diteliti. Riset ini menggali data, tanpa mengoperasionalisasi konsep atau menguji konsep pada realitas yang diteliti. Riset ini paling sederhana dan mendasar.

2) Jenis Deskriptif. Riset ini bertujuan membuat deskriptif secara sistematis, factual, dan akurat tentang fakta-fakta dan sifat-sifat populasi atau objek tertentu.

3) Jenis Eksplanatif. Riset ini menghubungkan atau mencari sebab akibat antara dua atau lebih konsep (variabel) yang akan diteliti. 
4) Jenis Evaluatif. Riset ini mengkaji efektivitas atau keberhasilan suatu program.

Berdasarkan pengertian diatas, peneliti memahami bahwa peneliti menggunakan jenis riset eksploratif, karena riset ini untuk menggali data, tanpa mengoperasionalisasikan konsep atau menguji konsep pada realitas yang diteliti. Riset ini paling sederhana dan mendasar, dimana periset langsung terjun ke lapangan dan semuanya dilaksanakan dilapangan, bahkan periset tidak memiliki konsep awal. "Key informan atau informan kunci menurut Robert K.Yin adalah mereka tak hanya memberikan keterangan tentang sesuatu kepada peneliti, tetapi juga memberikan saran tentang sumber-sumber yang bersangkutan." (Cangara, 2008)

Subjek penelitian ini adalah PR Manager PT. GO-JEK Indonesia ibu Rini Widuri Ragilia sebagai key informan kemudian PR Staff PT. GO-JEK Indonesia bapak Maulana Pandu sebagain informan I dan juga customer dari Go-Jek sebagai informan II saudari Cindy. Objek penelitian ini adalah kegiatan marketing public relations dalam meningkatkan brand awareness.

Teknik pengumpulan data dibagi menjadi dua bagian yang terdiri dari data primer yaitu melalui wawancara mendalam dengan key informan dan informan. Dengan wawancara mendalam (in-depth interview) kepada informan, peneliti dapat mengetahui alasan yang sebenarnya dari responden mengambil keputusan seperti itu. Informan adalah orang yang dapat memberikan keterangan atau informasi mengenai masalah yang sedang diteliti dan berperan sebagai narasumber selama proses penelitian (Ardianto, 2010). Data sekunder dapat didapat dari berbagai macam informasi yang berkaitan dengan Go-Jek Indonesia, baik berupa artikel, berita, maupun informasi pendukung yang diperoleh melalui media cetak maupun data internal yang sudah ada, dengan tujuan untuk memperoleh teori maupun konsep yang dapat digunakan sebagai dasar dalam pengembangan peneliti.

\section{Hasil Penemuan dan Diskusi}

PT. Go-Jek melakukan berbagai aktivitas untuk membangun kesadaran mereka perusahan di tengah persaingan yang ketat dalam bisnis tranportasi online. Persaingan tersebut memunculkan upaya yang serius dari PT. Go-Jek untuk melakukan aktivitas marketing public relations sebagai upaya menciptakan kesadaran mereka. Berdasarkan hasil penelitian yang menfokuskan pada upaya PT. Go-Jek menggunakan tools public relations melalui teori baruan public relations, yaitu P.E.N.C.I.L.S terdapat banyak kegiatan yang PT. Go-Jek Indonesia lakukan dalam meningkatkan brand awareness.

Aktivitas yang dilakukan PT-GO-JEK sebagai upaya meningkatkan kesadaran merek yaitu Pertama, Publications, PT. GOJEK Indonesia melalui publisitas memperluas informasi melalui berbagai media tentang aktifitas atau kegiatan perusahaan yang pantas untuk diketahui oleh publik. Publisitas sendiri merupakan strategi yang dapat menumbuhkan kepercayaan masyarakat karena dapat mempengaruhi cara berpikir masyarakat baik pada posisi merek maupun 
perusahaan. Dalam pelaksanaan publisitas, PT. Go-Jek mennggunakan sosial media sebagai medium publikasi utama. Hal tersebut merupakan implikasi dari pemanfaatan PT. Go-Jek terhadap internet dan smartphone. Media baru dan sosial media yang digunakan antara lain twitter, facebook dan website. Penggunaan media sosial terkait dengan konsumen PT. Go-Jek yang merupakan pengguna smartphone dan sekaligus pemilik sosial media yang mendukung publikasi dan pembentukan brand Go-Jek. Langkah ini, secara cepat dan masif dapat menunjang kegiatan publikasi yang dilakukan Go-Jek dalam memberikan informasi kepada mayarakat dan meningkatkan brand awareness kemasyarakat.

Kedua, Event yaitu event atau program acara yang bertujuan memperkenalkan produk dan layanan perusahaan, mendekatkan diri ke publik, dan lebih jauh lagi dapat mempengaruhi opini publik PT. Go-Jek Indonesia juga menjalin kerjasama dengan event-event besar selain untuk mendukung acara tersebut PT. Go-Jek Indonesia dapat memperkenalkan perusahaannya dan menjadi tempat promosi sehingga masyarakat akan semakin aware dengan Go-Jek. Kegiatan Go-Jek Tech ValleyValley Yogyakarta untuk mempertemukan teknoratteknorat muda negeri untuk mengubah Indonesia mulai dari kecil, mulai dari diri sendiri dan mulai dari sekarang. Event dalam bentuk kompetisi Go Video.com bertema "Indonesia pilih Go-Jek" pada tanggal 11 Mei 2016 di Gedung Perfilman Usman Ismail.

Go-Jek Indonesia mendukung kesuksesan acara "The 38th Jazz Goes To Campus, Thrill Is Back. Salah satu festival Jazz tertua di Indonesia yang telah diadakan pada hari Minggu 29 November 2015 di Fakultas Ekonomi dan Bisnis, Universitas Indonesia, Depok. GO-BOX hadir sebagai mitra transportasi resmi JGTC dan membuka booth untuk para pengunjung yang ingin mengetahui lebih banyak tentang GO-BOX dari Go-Jek. Go-Jek ikut serta dalam rangka mendukung dan juga sebagai promosi Go-Jek agar yang mengikuti event tersebut mengetahui lebih banyak tentang fitur baru yang dikeluarkan Go-Jek yaitu GOBOX.

Kegiatan-kegiatan yang diadakan tersebut ternyata berimplikasi logis terhadap peningkatan jumlah pengikut dimedia sosial Go-Jek saat ini dengan jumlah followers di twitter 310 ribu pengikut, instagram 169 ribu pengikut dan dan facebook mendapat 323.273 jumlah yang menyukai facebook dari Go-Jek dengan keterangan tersebut banyaknya yang mengikuti media sosial dari Go-Jek event yang diadakan dapat meningkatkan awareness dari masyarakat. Dengan banyaknya jumlah pengikut maka mayarakat mengikuti perkembangan Go-Jek. (Fikrie, 2016)

Ketiga, News. Berita selalu diperlukan dalam proses marketing public relations. Public Relations dituntut menciptakan berita melalui press release, news letter, bulletin dan berita yang diharapkan dapat mempengaruhi opini publik. Pemberitaan yang biasa dibuat oleh Go-Jek merupakan pemberitaan mengenai kerjasama yang dilakukan Go-Jek dengan perusahaan-perusahaan lain dilakukan publikasi melalui website Go-Jek sendiri maupun kemedia massa lainnya. Dengan berita-berita baik yang dibuat oleh Go-Jek sendiri maupun pemberitaan mengenai Go-Jek yang terdapat dimedia massa dapat mempengaruhi pandangan masyarakat terhadap perusahaan, dengan pemberitaan yang segera diklarifikasi dan 
pemberitaan yang dirasa positif akan dapat menciptakan pandangan positif masyarakat akan Go-Jek. Pandangan tersebut akan meningkatkan pula brand awareness masyarakat akan Go-Jek sehingga mereka dapat setia dengan layanan yang terdapat pada Go-Jek.

Kempat, Community Involvement. Salah satu pembentukan kesadaran yang paling kuat adalah melalui komunitas PT. Go-Jek Indonesia memiliki kerjasama dengan banyak komunitas dan membuka bagi komunitas yang ingin bekerjasama seperti tukang ojek yang ingin bergabung menjadi mitra Go-Jek atau para UKM (usaha kecil dan menengah) atau outlet makanan yang ingin bergabung dengan salah satu fitur dari Go-Jek yaitu GO-FOOD. Tidak hanya karena bisnis Go-Jek juga dapat menjadikan wadah bagi para komunitas agar bisa dapat lebih mensejahterakan usahanya. Dengan kerjasama tersebut juga dapat memberikan keuntungan baik pada perusahaan maupun mitra yang bergabung dengan Gojek. Adanya kerjasama tersebut maka dapat memberikan kesadaran masyarakat akan sebuah perusahaan ataupun komunitasnya.

Dalam menjalin hubungan baik dengan komunitas Go-Jek juga memberikan beberapa penghargaan bagi mitra Go-Jek yang menurut Go-Jek sudah memberikan dedikasi yang patut untuk diberi penghargaan. Tidak hanya kepada mitra namun juga kepada pedagang terbaik juga kepada konsumen setia Go-Jek.

Kelima, Inform or Image. Memberitahukan informasi menarik kepada publik sehingga diharapkan akan memperoleh citra positif. Proses dari "nothing" menjadi "something" dari yang tidak tau menjadi tau setelah itu menjadi suka dan kemudian diharapkan timbul sesuatu berupa citra. Citra positif perusahaan yang diraih juga merupakan citra baik bagi para mitra karena membuat profesi mereka dipandang sebelah mata lagi, dengan rasa bangga telah bekerja dalam perusahaan bercitra positif dapat memicu motivasi mereka untuk dapat bekerja lebih produktif.Pentingnya citra positif dari sebuah perusahaan akan dapat mempengaruhi kegiatan marketing perusahaan. Dengan citra positif perusahaan akan memudahkan mendapat kerjasama dengan perusahaan lain karena pandangan positif terhadap perusahaan mereka akan merasa percaya apabila menjalin kerjasama. Dengan memberikan apa yang masyarakat butuhkan Go-Jek berharap mendapatkan citra yang positif dari masyarakat.

Keenam, Lobbying and Negotiation. Proses lobbying and negotiation yang dilakukan oleh Go-Jek kepada pemerintah dimana sebuah perusahaan membutuhkan perizinan dari pemerintah untuk mendirikan perusahaan sehingga dalam berjalannya perusahaan dapat berjalan lancar. Selain lobbying and negotiation kepada pemerintah Go-Jek juga melakukan proses lobbying and negotiation kepada tukang ojek pangkalan untuk mengajak mereka lebih terorganisir dibawah naungan Go-Jek. Dengan turun langung kejalan untuk dapat mengajak para tukang ojek yang dimana mereka bersifat independen dan harus bekerja nantinya dengan sistem operasi yang sesuai dengan perusahaan. Melalui pendekatan dan pembinaan kini Go-Jek memiliki mitra driver terbanyak dibanding dengan ojek online lainnya. 
Ketujuh, Social Responsibility.Tanggung jawab sosial merupakan perusahaan merupakan bentuk kerja sosial perusahaan kepada masayraakat. Dalam aktifitas PR menunjukan bahwa perusahaan memiliki kepedulian terhadap masyarakat. Seperti yang dilakukan oleh Go-Jek yaitu kerjasama dengan rumah zakat, saat terjadi bom di Sarinah juga Go-Jek membantu dengan mengevakuasi masyarakat ke tempat yang lebih aman secara gratis. Membuka lapangan pekerjaan kepada usaha kecil dan menengah untuk mensejahterakan usaha mereka. Selain dalam hal sosial yang tertera diatas Go-Jek juga melakukan tanggungjawab sosial dalam bentuk ajakan bergabung dengan Go-Jek agar usaha mereka lebih sejahtera Go-Jek juga turut dalam mengurangi angka penganguran di Indonesia karena.

Semua aktivitas marketing public relatios yang dilakukan PT. Go-Jek mengakui bahwa semua berpengaruh dalam meningkatkan brand awareness perusahaan. Semua kegiatan diatas dapat saling berkesinambungan dalam meningkatkan brand awareness. Publikasi, membuat acara yang menarik, meningkatkan citra menjadi lebih baik serta menjalin hubungan baik dengan komunitas merupakan kegiatan yang sering mereka terapkan. Go-Jek meningkatkan pula kualiatas pelayanan agar dapat membuat konsumen merasa terpuaskan dan terus setia menggunakan Go-Jek sebagai aplikasi mobile dalam memenuhi kebutuhannya sehari-hari.

Agar suatu proses perencanaan, pelaksanaan, dan pengevaluasian program-program dapat berjalan sesuai dengan tujuan perusahaan, maka peran Marketing Public Relations harus dapat melakukan kegiatan-kegiatan dalam menjalankan setiap kegiatannya, melalui proses dan kegiatan komunikasi dan informasi yang dapat dipercaya dan melalui kesan-kesan positif yang ditimbulkan yang berkaitan dengan identitas perusahaan atau produknya sesuai dengan kebutuhan, keinginan, perhatian, dan kepentingan bagi para konsumen.

Go-Jek adalah Identitas yang membentuk suatu image sangat diperlukan oleh perusahaan-perusahaan untuk tetap menarik perhatian konsumen. Tentunya sangat diperlukan diciptakannya suatu image untuk melambangkan identitas perusahaan agar tetap bisa bertahan dan mampu untuk survive dalam persaingan yang semakin keras ini. Identitas juga menjadi ciri untuk membedakan dengan kompetitor lain. Pentingnya sebuah identitas juga bertujuan agar masyarakat mengetahui kemudian mengenal dan mengingat perusahaan tersebut.

Go-Jek mempunyai ciri khas warna hijau dan hitam ditulisan GO-JEK yang ditengah-tengahnya terdapat gambar motor atau ojek disetiap atribut yang driver kenakan. Pembentukan identitas diatas merupakan sebuah logo dimana logo merupakan cara untuk meningkatkan brand awareness masyarakat terhadap sebuah perusahaan. Jika sebuah perusahaan tidak memiliki logo maka hal itu akan meningkatkan keraguan dan pikiran negatif terhadap perusahaan tersebut. Go-Jek tetap fokus pada tagline yang dibuat Go-Jek yaitu "Ojek For Every Need", GoJek akan berusaha tetap memberikan pelayanan yang masyarakat butuhkan dengan sebaik-baiknya.

Mengadakan promosi juga merupakan cara yang cukup efektif dalam menarik minat masyarakat untuk mencoba produk atau layanan yang disediakan sebuah perusahaan. Dimana setiap perusahaan pasti melakukan promosi dengan 
semenarik mungkin, begitupun promosi-promosi yang dilakukan pihak Go-Jek untuk menarik perhatian masyarakat dan tertarik untuk mencoba layanannya. Seperti setiap peluncuran fitur baru yang diadakan Go-Jek, yaitu promo Go-Ride diskon $50 \%$ jika menggunakan GO-PAY yang merupakan fitur terbaru dari GoJek.

Dengan kegiatan-kegiatan marketing yang telah dilakukan Go-Jek dari mulai survei pasar melihat apa yang dibutuhkan masyarakat dan menyesuaikan dengan majunya teknologi saat ini serta mengadakan promosi untuk menarik minat masyarakat untuk mencoba jasa Go-Jek kemudian mereka akan mengenal dan mengetahui bagaimana pelayanannya akan menciptakan sebuah citra dengan citra yang terbentuk kemudian semakin aware akan Go-Jek dan kemudian mereka akan loyal.

Selain kegiatan promosi yang perlu dilakukan adalah mengembangkan pelayanan lain yang terdapat dalam aplikasi. mengembangkan fitur lain yang terdapat pada Go-Jek juga merupakan kegiatan marketing agar tetap dapat memikat masyarakat agar terus menggunakan Go-Jek sehingga walaupun tidak adanya promosi harga yang terdapat pada layanan GO-RIDE layanan yang masih sering digunakan oleh konsumen, Go-Jek tidak merasa khawatir karena masih terdapat layanan lainnya yang tidak dimiliki oleh perusahaan ojek online lainnya. Dengan perbedaan fitur dapat dijadikan identitas perusahaan dan dapat meningkatkan brand awareness.

Dengan perkembangannya Go-Jek medapatkan banyak penghargaan, beberapa penghargaan tersebut merupakan penghargaan bergengsi. Seperti juara 1 dalam kompetisi bisnis Global Enterpreuner Program Indonesia (GEPI) di Bali, kemudian CEO dari Go-Jek Nadiem Makariem menerima penghargaan dari Jawapos sebagai salah satu pengusaha muda terbaik 2016. Selain itu, Go-Jek telah memperoleh berbagai penghargaan dari komunitas bisnis sosial. Dengan prestasi yang diperoleh oleh Go-Jek maka citra positif patut disandang oleh Go-Jek. Citra yang positif akan meningkatkan brand awareness Go-Jek kepada masyarakat.

Dengan kegiatan-kegiatan yang dilakukan Go-Jek dalam meningkatkan brand awareness-nya yaitu menggunakan tagline pendek yang mudah diingat oleh masyarakat dengan arti ojek yang dapat membantu dalam keseharian masyarakat. Go-Jek juga mengembangkan simbol atau logo Go-Jek yaitu warna yang mayoritas warna hijau dengan gambar ojek ditengah tulisan "GO-JEK" pada atribut yang mitra Go-Jek kenakan seperti seragam, jaket, helm dan atribut lainnya untuk membantu pelanggan sadar akan merek Go-Jek. Go-Jek juga melakukan publisitas untuk memberikan informasi kepada masyarakat tentang apapun informasi yang perlu untuk diinformasikan kepada khalayak seperti promosi ataupun pemberitahuan tentang fitur layanan atau apapun.

Go-Jek tidak pernah puas mereka akan terus menaikkan tingkat service atau pelayan yang ada dalam Go-Jek sehingga masyarakat pengguna Go-Jek akan lebih nyaman dan puas karena pastinya perusahaan lain akan melakukan kegiatankegiatan marketing yang lebih menarik. Kemudian Go-Jek harus lebih meluaskan jaringannya hingga semua masyarakat Indonesia dapat merasakan mengakses aplikasi Go-Jek dengan perluasan jaringan maka masyarakat akan lebih aware dan dapat makin meningkatkan brand. 


\section{Simpulan}

PR PT. GOJEK Indonesia menerapkan strategi marketing yang disebutkan oleh Thomas L. Harris yaitu Publicity, Event, News, Community Involvement, Inform to Image, Lobbying and Negotiation, dan Social Responsibility dalam memperkenalkan Go-Jek kemasyarakat luas dan menjadikan aplikasi mobile favorit masyarakat khususnya di kota-kota besar Indonesia dimana para era globalisasi dibutuhkan sesuatu yang efektif dan efesien sehingga Go-Jek dengan tagline-nya dapat memenuhi kebutuhan masyarakat saat ini.

Dalam proses meningkatkan brand awareness perusahaan Go-Jek menggunakan beberapa strategi, strategi yang dilakukan Go-Jek sudah berhasil dengan mendapatkan hasil yang positif dari masyarakat. Dimana dengan menciptakan citra yang positif akan menimbulkan kepercayaan, dari kepercayaan tersebut maka mereka akan mencoba untuk lebih mengenal kemudian mereka akan merasa nyaman dan loyal terhadap perusahaan. Dengan kegiatan-kegiatan dari strategi tersebut yang dilakukan Go-Jek menjaga hubungan baik dengan konsumen, masyarakat, dan komunitas serta selalu memberikan pelayanan dan fitur yang dapat memenuhi kebutuhan masyarakat untuk mendapatkan awareness dan loyalitas masyarakat terhadap perusahaan.

Go-Jek mampu memperkenalkan perusahaannya dengan memberikan pelayanan-pelayanan yang berbeda dari yang lainnya. Go-Jek berani dalam berinovasi dengan menciptakan fitur yang tidak biasa kepada masyarakat dan hal tersebut dapat diterima secara baik oleh masyarakat, bahkan dengan berbedanya fitur layanan yang dibuat Go-Jek mendapatkan sambutan baik oleh mayarakat. Dengan perbedaannya tersebut Go-Jek dapat menjadikan perusahaannya sebagai perusahaan ojek berbasis online terunggul dibanding dengan ojek berbasis online lainnya.

\section{Ucapan Terima Kasih}

Ucapan terima kasih penulis berikan kepada seluruh narasumber yang terlah bersedia untuk membantu selama proses penelitian ini berlangsung. Kemudian juga kepada seluruh pihak-pihak terkait yang tidak dapat disebutkan satu per satu.

\section{Daftar Pustaka}

Alportal. (n.d.). Data Pengguna Internet di Indonesia. Juli 15, 2016. Retrieved from: http://alportal.com/...4/data-pengguna-internet-di-indonesia.

Ardianto, E. (2010). Metodologi Penelitian Untuk Public Relations Kuantitatif dan Kualitatif. Bandung: Simbiosa Rekatama Media.

Cangara, H. (2008). Pengantar Ilmu Komunikasi. Jakarta: Raja Grafindo Persada.

Devi, Zeilla Mutia. (2015, Oktober 05). Ojek Pangkalan Tak Boleh Kalah dengan Ojek Online. Retrieved Mei 29, 2017, from Marketeers: http://marketeers.com/ojek-pangkalan-tak-boleh-kalah-dengan-ojekonline/ 
Durianto, Darmadi, Sugiarto dan Lie Joko Budiman. (2004). Brand Equity Ten: Stategi memimpin Pasar. Jakarta: PT Gramedia Pustaka Utama.

Ehpedia. (2015). Apa itu Gojek. Retrieved Januari 15, 2016, from Ehpedia: http://www.ehpedia.com/2015/08/apa-itu-Go-Jek-adalah.html

Fikrie, Muammar. (2016, April 21). Jargon Nasionalisme Go-Jek Berbuah Respon Negatif. Retrieved Mei 29, 2017, from Beritaajar.id : https://beritagar.id/artikel/berita/jargon-nasionalisme-Go-Jek-berbuahrespons-negatif

Harris, T. L., \& Whalen, P. A. (2006). The Marketer's Guide To Public Relations In The 21 st Century. USA.

Iklanwww.Go-Jek.com/gojekin-aja. GO-RIDE, GO-CAR, GO-FOOD, GO-SEND dan Lainnya Dalam Satu Aplikasi, GO-JEKin Aja! Mudah \& Aman $\cdot 100 \%$ Karya Anak Bangsa

Kriyantono, R. (2010). Teknik Praktis Riset Public Relations. Jakarta: Kencana Prenada Media Group.

MarkPlus, T. (2009). Markplus Basic Pengantar Hermawan Kartajaya. Jakarta: ESSENSI.

Mulyana, D. (2003). Metodologi Penelitian Kualitatif Paradigma Baru Ilmu Komunikasi dan Ilmu Sosial Lainnya. Bandung: Remaja Rosdakarya.

Polit, D. F., Beck, C. T., \& Hungler. (2004). Canadian Essential of Nursing Research. Philadelpia: Lippincot.

Ruslan, R. (2010). Manajemen dan Public Relations dan Media Komunikasi. Jakarta: Raja Grafindo Persada.

Ruslan, R. (2013). Kiat dan Strategi Kampanye Public Relations. Jakarta: Grafindo Persada.

Salim, A. (2006). Teori dan Paradigma Penelitian Sosial. Jakarta: Erlangga.

Sekilas Sejarah Perkembangan Mengenai Go-Jek. (n.d.). Retrieved November 14, 2015, from https://www.Go-Jek.com

Shimp, T. A. (2003). Periklanan Promosi Aspek Tambahan Komunikasi Pemasaran Terpadu. Jakarta: Erlangga.

Winarta, Karmin. (2015, September 18). 6 Ojek Online yang Menjadi Pesaing Gojek. Retrieved Oktober 10, 2015, from Liputan6 Online: http://citizen6.liputan6.com/read/2320466/6-ojek-online-yang-menjadipesaing-gojek

www. tekno.liputan6.com > Tekno > Internet, 3 Fakta Mengejutkan Pengguna Internet di Indonesia - Tekno. Tekno Liputan6.com dari laman We Are Social, Minggu (14/2/2016). Diakses pada Senin, 3 September 2016 Pukul 13.45 WIB. 